\title{
Motivasi dan Hasil Belajar IPA dalam Pembelajaran Scramble Berbantuan Kartu Pertanyaan
}

\author{
*Ni Ketut Mira Adnyani1 ${ }^{\text {, Ketut Pudjawan², I Gusti Ngurah Japa }}{ }^{3}$
}

1.3Program Studi Pendidikan Guru Sekolah Dasar, Jurusan Pendidikan Dasar, Universitas Pendidikan Ganesha, Singaraja, Indonesia

${ }^{2}$ Program Studi Teknologi Pendidikan, Jurusan Ilmu Pendidikan, Psikologi dan Bimbingan, Universitas Pendidikan Ganesha, Singaraja

\author{
A R T I C L E I N F O \\ Article history: \\ 1 Maret 2020 Received in \\ revised form \\ 30 Maret 2020 \\ Accepted 11 April 2020 \\ Available online 15 \\ Mei 2020

\section{Kata Kunci:} \\ scramble, motivasi, hasil \\ belajar IPA \\ Keywords: \\ Scramble, Motivation, \\ Learning Achievement of \\ Science Subject
} (Manova). Hasil penelitian menunjukkan bahwa: 1) terdapat yang signifikan pengaruh model pembelajaran Scramble berbantuan kartu pertanyaan terhadap motivasi belajar ( $F=62,487$, dengan Sig. < 0,05); 2) terdapat pengaruh yang signifikan model pembelajaran Scramble berbantuan kartu pertanyaan terhadap hasil belajar IPA ( $F=18,344$, dengan Sig. < 0,05); 3) secara simultan terdapat pengaruh yang signifikan model pembelajaran Scramble terhadap motivasi belajar dan hasil belajar IPA $(F=30.964$, dengan Sig. $<0,05)$. Jadi, dengan adanya model model pembelajaran Scramble mempengaruhi hasil belajar dan motivasi belajar.

\begin{abstract}
A B S T R A C T
Students in learning activities only accept material taught by the teacher without understanding the problem or investigate the problem to find the answer. This research aimed at determining the effect of the Scramble aided question cards on the motivation and learning outcomes on fifth grade students in natural science. The population in this research was 156 students and all of them was on fifth grade. While the research sample consisted of 27 students on fifth grade students at SD Negeri 1 Banjar Tegal as an experimental group and grade fifth grade students of SD Negeri 1 Baktiseraga as a control group which totalled 26 students were selected by using the random sampling technique. Data collection of learning motivation variables used learning motivation questionnaires and science learning outcome variables used multiple choice tests. The hypothesis in this research was tested by using multivariate analysis techniques (Manova). The results showed that: 1) there was a significant effect on the Scramble learning model aided by question cards on learning motivation $(F=62.487$, with Sig. $<0.05)$; 2) there was a significant influence on the Scramble learning model aided by question cards on the learning outcomes of natural sciences ( $F=18,344$, with Sig. $<0.05)$; 3) simultaneously there was a significant effect of Scramble learning model on learning motivation and natural science learning outcomes $(F=30,964$, with Sig. $<0.05)$. So, the scramble learning model had an effect in learning outcomes and learning motivation.
\end{abstract}




\section{Pendahuluan}

Dunia pendidikan selalu mendapat sorotan tajam terkait dengan tuntunan dalam menghasilkan sumber daya manusia yang dapat memberikan dampak terkait dengan pendidikan. Sumber daya manusia yang berkualitas diharapkan dapat mengikuti perkembangan Ilmu Pengetahuan dan Teknologi (IPTEK) yang berkembang saat ini. Pembangunan dalam upaya peningkatan mutu pendidikan hendaknya dapat memberikan dampak terkait dengan pendidikan kearah yang lebih baik. Pendidikan adalah hak semua anak. Sehingga pendidikan dianggap sebagai sebuah hak asasi manusia yang menjadikan secara bebas dapat dimiliki oleh semua anak (Wisudawati,dkk 2019).

Melalui pendidikan peserta didik disediakan berbagai kesempatan belajar dalam upaya peningkatan pendidikan baik bidang pengetahuan, keterampilan dan sikap maupun keperluan dirinya dengan kehidupan masyarakat. Untuk itu, pendidikan pada saat ini harus mencerminkan pada empat pilar pendidikan yang terdiri dari: (1) learning to kow dimana dalam pendidikan program guru yang dibelajarkan kepada peserta didik dapat mengembangkan penguasaan pengetahuan dalam siswa dalam belajar; (2) learning to do dalam pendidikan tidak hanya sekadar mengetahui, tetapi sebagai seorang guru dapat mengajak peserta didik dalam melakukan sesuatu sehingga dapat mengasilkan sesuatu yang bermakna bagi kehidupan; (3) learning to be pembelajaran dapat memberikan motivasi sehingga memberikan orinteasi hidupnya ke masa depan; (4) learning to live together pembelajaran tidak cukup hanya diberikan keterampilan untuk diri sendiri, sebagai bekal untuk mmapu berperan dalam lingkungan bermasyarakat (Wiandariyani, dkk., 2011). Dengan demikian pendidikan saat ini harus membekali peserta didik baik pengetahuan kognitif, afektif, dan psikomotorik sebagai mencerminkan ke empat pilar pendidikan tersebut, yang tidak semata-mata penguasaan pada aspek pendidikan.

Untuk mencapai tujuan tersebut, berbagai usaha telah dilakukan oleh pemerintah untuk memperbaiki dan meningkatkan mutu pendidikan, yaitu: (1) dengan melakukan penyempurnaan kurikulum, (2) melakukan penataran terkait sistem pendidikan pembelajaran, (3) penyediaan sarana dan prasarana dalam penunjang kegiatan pembelajaran, (4) penyediaan bahan ajar serta buku referensi yang menunjang kegiatan belajar, (5) adanya kegiatan kelompok kerja guru sering disingkat dengan (KKG). Dalam penyempurnaan kurikulum di Indonesia telah disempurnakan menjadi kurikulum 2013 (K-13). Kurikulum 2013 bertujuan untuk mengembangkan potensi peserta didik baik kemampuan sikap religius, sikap social, intelektual, sikap peduli dan partisipasi aktif di dalam membangun kehidupan berbangsa serta bermasyarakat yang lebih baik.

Dalam pembelajaran Kurikulum 2013 menggunakan tematik integratif. Tematik integratif adalah pokok bahasan pelajaran dipadukan berdasarkan tema dengan menggabungkan beberapa pelajaran menjadi satu (Kristiantari, 2014). Salah satu mata pelajaran yang dipadukan dan dimuat dalam kurikulum 2013 adalah mata pelajaran Ilmu Pengetahuan Alam (IPA). Wisudawati, dkk. (2019) IPA merupakan rumpun ilmu, memiliki karakteristik khusus yaitu mempelajari fenomena alam yang faktual, baik berupa kenyataan (reality) atau kejadian (events) serta hubungan sebab akibatnya. Salah satu tujuan mata pelajaran IPA di Sekolah Dasar sesuai dengan Peraturan Menteri Pendidikan Nasional Republik Indonesia No. 22 Tahun 2006 bahwa agar peserta didik memiliki kemampuan didalam mengembangkan pengetahuan, rasa ingin tahu, sikap positif serta keterampilan yang dapat diterapkan dalam kehidupannya. Dengan demikian, mata pembelajaran IPA diharapkan dapat menjadi wahana bagi peserta didik dalam mempelajari diri sendiri dan alam sekitar, serta prospek dalam pengembangan di dalam kehidupan sehari-hari. Berdasarkan hasil observasi, wawancara dan pencacatan dokumen yang dilakukan di SD Gugus XIII Kecamatan Buleleng yang dilakukan pada tanggal 18-20 Oktober 2019 dengan guru kelas V di SD Gugus XIII Kecamatan Buleleng. Hasil yang diperoleh sebagai berikut.

Pertama, berdasarkan hasil observasi yang telah dilaksanakan proses pembelajaran IPA di Kelas V Gugus XIII Kecamatan Buleleng masih didominasi oleh guru. Dimana dalam pembelajaran IPA guru menggunakan metode pembelajaran berupa metode tanya jawab dan memberikan ceramah berupa mentransfer begitu saja apa-apa yang diuraikan dalam buku siswa sehingga dalam pembelajaran masih berpusat kepada guru (teacher center), guru hanya menggunakan buku siswa sebagai sumber belajar tanpa memanfatkan sumber belajar yang lainnya, guru jarang menggunakan media saat proses pembelajaran, dan dalam mengajar guru jarang menggunakan model pembelajaran yang bervariasi. Sehingga mengakibatkan pembelajaran menjadi kurang menarik dan menyenangkan.

Sedangkan dari siswanya dalam kegiatan pembelajaran hanya menerima saja materi yang diajarkan oleh guru, tanpa memahami permasalahan maupun menyelidiki permasalahan tersebut untuk menemukan jawabannya. Kecenderungan itu membuktikan bahwa siswa hanya menerima materi yang diberikan sehingga menyebabkan siswa menjadi pasif. Proses pembelajaran akan menjadi membosankan sehingga akan mempengaruhi motivasi dan hasil belajar siswa. 
Kedua, berdasarkan hasil wawancara bersama sebagian besar guru kelas V di Gugus XIII Kecamatan Buleleng diperoleh hasil dimana masih banyak siswa yang mengalami kesulitan dalam pembelajaran IPA, siswa kurang antusias dalam kegiatan pembelajaran, siswa kurang berkosentrasi dalam menerima pembelajaran, siswa sering terlambat masuk ke kelas ketika jam pelajaran sudah dimulai.

Ketiga, berdasarkan pencatatan dokumentasi terkait dengan nilai pengetahuan IPA, maka diperoleh bahwa data hasil belajar Ulangan Tengah Semester (UTS) mata pelajaran IPA pada siswa kelas V di Gugus XIII Kecamatan Buleleng masih rendah atau di bawah KKM. Hasil tersebut dapat dilihat pada Tabel 01.

Tabel 01. Data Hasil Belajar UTS IPA Siswa Kelas V Semester I di Gugus XIII Kecamatan Buleleng Tahun Pelajaran 2019/2020

\begin{tabular}{|c|c|c|c|c|c|c|c|}
\hline \multirow{2}{*}{ No. } & \multirow{2}{*}{ Nama Sekolah } & \multirow{2}{*}{ Kelas } & \multirow{2}{*}{ KKM } & \multicolumn{2}{|c|}{$\begin{array}{l}\text { Siswa yang sudah } \\
\text { mencapai KKM }\end{array}$} & \multicolumn{2}{|c|}{$\begin{array}{l}\text { Siswa yang belum } \\
\text { mencapai KKM }\end{array}$} \\
\hline & & & & Tuntas & $\begin{array}{c}\text { Persentase } \\
(\%)\end{array}$ & $\begin{array}{c}\text { Tidak } \\
\text { Tuntas }\end{array}$ & $\begin{array}{l}\text { Persentase } \\
(\%)\end{array}$ \\
\hline 1 & SD N 1 Banjar Tegal & $\mathrm{V}$ & 70 & 13 & $48 \%$ & 14 & $52 \%$ \\
\hline 2 & SD N 2 Banjar Tegal & V & 75 & 7 & $50 \%$ & 7 & $50 \%$ \\
\hline 3 & SD N 3 Banjar Tegal & V & 70 & 2 & $77 \%$ & 10 & $83 \%$ \\
\hline \multirow[t]{2}{*}{4} & SD N 1 Baktiseraga & VA & 70 & 10 & $38 \%$ & 16 & $62 \%$ \\
\hline & & VB & 70 & 9 & $35 \%$ & 17 & $65 \%$ \\
\hline \multirow[t]{2}{*}{5} & SD Mutiara & VA & 75 & 5 & $19 \%$ & 21 & $81 \%$ \\
\hline & & VB & 75 & 4 & $16 \%$ & 21 & $84 \%$ \\
\hline
\end{tabular}

Berdasarkan tabel 01 di atas, dapat terlihat bahwa masih terdapat kesenjangan diantara harapan dengan kenyatan. Hal ini tersebut terlihat dari jumlah siswa yang belum tuntas lebih banyak dibandingkan dengan jumlah siswa yang tuntas. Selain itu, dilihat dari persentase siswa yang tuntas yaitu 16\% sampai 50\%, yang jika dikategorikan masih rendah. Maka dengan demikian, hasil belajar IPA siswa kelas V pada Gugus XIII masih kategori kurang sehingga berdampak terhadap motivasi belajar dan hasil belajar siswa pada mata pelajaran IPA. Maka perlu adanya perbaikan dalam pembelajaran untuk mengatasi motivasi dan hasil belajar siswa pada mata pelajaran IPA. Salah satu cara yang dapat dilakukan adalah menggunakan model pembelajaran dan media pembelajaran yang tepat, sebab dengan menggunakan media pembelajaran siswa akan lebih mudah menerima pembelajaran dan aktif dalam proses pembelajaran. Salah satu alternatif untuk mengatasi masalah tersebut dapat diterapkan model kooperatif tipe Scramble.

Model pembelajaran kooperatif tipe scramble adalah salah satu model permainan secara berkelompok dengan mencocokan kartu pertanyaan dan kartu jawaban yang telah disediakan. Suyatno (2009:72) menyatakan bahwa,"model pembelajaran scramble merupakan salah satu tipe pembelajaran yang disajikan dengan bentuk kartu dengan mencari pasangan jawaban dari pertanyaan yang jawabanya diacak". Selama proses pembelajaran dengan model scramble siswa melakukan diskusi kelompok atau berinteraksi dengan temannya dalam menemukan dan memahami konsep pembelajaran karena dengan berinteraksi siswa akan lebih mudah menyerap materi pembelajaran di kelas (Sya'ban 2016). Maka dengan model Scramble dapat meningkatkan motivasi belajar dan hasil belajar. Pembelajaran kooperatif ini dapat merangsang aktivitas belajar, meningkatkan tingkat pencapaian dan dan meningkatkan motivasi, partisipasi kelas dan prestasi akademik siswa sehingga dalam belajar suasana belajar yang meneyenangkan (Gull, 2015; Tran, 2014). Selanjutnya Saridewi, (2017) model pembelajaran scramble merupakan salah satu strategi pembelajaran motivasional yang diyakini dapat meningkatkan motivasi dan prestasi siswa dalam belajar.

Menurut Farida (2017) dalam menanggulangi permaslah belajar dibutuhkan dorongan dan inspirasi untuk mengatasi masalah tersebut dengan menggunakan strategi pembelajaran inovatif dan 
menciptakan situasi baru yang menyenangkan yaitu suatu model yang dapat diterapkan dalam proses pembelajaran untuk meningkatkan kemampuan berpikir kritis siswa. Salah satu yang dinilai efektif dan mampu memotivasi siswa dalam pembelajaran IPA adalah model Scramble.

Selain itu, untuk meningkatkan kualitas proses pembelajaran IPA diperlukan adanya pemanfaatan media pembelajaran. Arsyad (2017) media pembelajaran adalah segala sesuatu yang dapat digunakan untuk menyampaikan pesan dalam proses pembelajaran sehingga dapat merangsang perhatian dan minat dalam belajar. Dalam hal ini media yang digunakan adalah kartu pertanyaan. Kartu pertanyaan adalah sarana agar siswa dapat secara aktif, berpikir kritis di dalam belajar dan secara inovatif dapat menemukan cara-cara atau pembuktian teori dalam pembelajaran. Media kartu pertanyaan ini sangat mudah dibuat oleh guru serta memudahkan siswa dalam memahami materi pembelajaran. Ramadani, (2014) model pembelajaran scramble berbantuan kartu pertanyaan dapat membantu siswa dalam menumbuhkan keaktifan dan keantusiasan dalam mengikuti proses pembelajaran. Dengan demikian penggunaan model pembelajaran scramble berbantuan kartu pertanyaan membawa pengaruh positif terhadap proses belajar siswa yaitu peningkatan motivasi dan hasil belajar siswa pada pelajaran IPA. Penelitian ini dilakukan dasar penelitian yang sebelumnya yang telah dilakukan oleh Citrasmi, dkk, (2016), menunjukkan peningkatan hasil belajar IPA dengan menggunakan model pembelajaran scramble berbantuan media gambar. Selanjutnya Suryanta, dkk. (2014), menunjukkan peningkatan hasil belajar IPA dengan menggunakan model pembelajaran scramble berbantuan media gambar animasi. Selanjutnya Astriani (2019), menunjukkan bahwa menunjukkan peningkatan hasil belajar IPA dengan menggunakan model pembelajaran scramble berbantuan media gambar. Disamping penggunaan model pembelajaran dan media pembelajaran, sebagai seorang guru memiliki peranan penting dalam upaya meningkatkan motivasi dan hasil belajar yang diperoleh siswa. Mc. Donald (dalam Sadiman, 2011) motivasi adalah perubahan energi dalam diri seseorang yang ditandai dengan munculnya "feeling" yang didahului dengan tanggapan terhadap adanya tujuan. Tujuan yang diharapkan pen didikan khususnya di sekolah dasar adalah hasil belajar yang maksimal dengan adanya motivasi belajar siswa dalam belajar. Dengan demikian, motivasi belajar dan hasil belajar siswa dapat mencapai ketuntasan KKM. Dengan demikan menunjukkan keberhasilan siswa dan guru dalam melaksanakan proses pembelajaran.

Berdasarkan uraian di atas, dapat dilakukan suatu penelitian untuk membuktikan adanya pengaruh model pembelajaran Scramble berbantuan kartu pertanyaan terhadap motivasi dan hasil belajar siswa mata pelajaran IPA. Dengan demikian, penelitian yang dilakukan berjudul "Pengaruh Model Pembelajaran Scramble Berbantuan Kartu Pertanyaan Terhadap Motivasi dan Hasil Belajar IPA Kelas V Gugus XIII Kecamatan Buleleng Tahun Pelajaran 2019/2020".

Adapun tujuan penelitian ini adalah untuk mengetahui pengaruh model pembelajaran Scramble berbantuan kartu pertanyaan terhadap motivasi belajar dan hasil belajar IPA siswa kelas V Gugus XIII Kecamatan Buleleng. Perbedaan penelitian yang sudah ada dengan dalam penelitian ini adalah dalam penelitian ini mengetahui pengaruh model pembelajaran Scramble berbantuan kartu pertanyaan terhadap motivasi belajar dan hasil belajar IPA. Sedangkan pada penelitian yang sudah ada hanya mengukur hasil belajarnya saja.

\section{Metode}

Jenis penelitian ini adalah penelitian eksperimen semu (quasi experiment). Rancangan penelitian yang digunakan adalah posttest-only control-group desain. Agung (2014:69) "populasi adalah keseluruhan subjek penelitian". Dalam penelitian ini adalah semua siswa kelas V SD Gugus XIII Kecamatan Buleleng yakni sebanyak 156 orang, dengan rincian anggota populasi dalam penelitian dapat dilihat tabel 02 berikut.

Tabel 02. Data Jumlah Anggota Populasi Penelitian

\begin{tabular}{cll}
\hline No. & Nama Sekolah Dasar & Jumlah Siswa Kelas V \\
\hline 1 & SD Negeri 1 Banjar Tegal & 27 \\
2 & SD Negeri 2 Banjar Tegal & 14 \\
3 & SD Negeri 3 Banjar Tegal & 12 \\
4 & SD Negeri 1 Baktiseraga & 52 \\
5 & SD Mutiara Singaraja & 51 \\
\hline & Jumlah total populasi & 156 \\
\hline
\end{tabular}


Dalam penelitian ini, sampel ditentukan dengan menggunakan teknik random sampling. Sampel penelitian yang terpilih berdasakan hasil pengundian yaitu siswa kelas V SD Negeri 1 Banjar Tegal sebagai kelompok eksperimen dengan jumlah 27 orang dan siswa kelas VA SD Negeri 1 Baktiseraga sebagai kelompok kontrol dengan jumlah 26 orang. Penelitian ini melibatkan dia variabel yaitu variabel bebas dan variabel terikat. Variabel bebas dalam penelitian ini adalah model pembelajaran Scramble berbantuan kartu pertanyaan dan tidak mendapat perlakuan model pembelajaran Scramble berbantuan kartu pertanyaan dan variabel terikatnya adalah motivasi belajar dan hasil belajar IPA. Metode pengumpulan data dalam penelitian ini adalah non tes dan tes. Non tes untuk mengukur motivasi belajar siswa berupa pemberian kuesioner diakhir pembelajaran. Dengan indikator yang diukur untuk kuesioner motivasi belajar terdiri dari: (1) adanya hasrat dan keinginan berhasil, (2) tekun mengerjakan tugas terus menerus dalam waktu lama, tidak pernah berhenti sebelum selesai, (3) ulet menghadapi kesulitan (tidak lekas putus asa),(4) cepat bosan dengan tugas-tugas yang rutin,(5) adanya penghargaan dalam belajar, dan (6) senang mencari dan memecahkan masalah soal-soal. Sedangkan untuk data mengenai hasil belajar IPA dikumpulkan dengan memberikan tes pilihan ganda dengan Kompetensi Dasar (KD) yaitu: 3.6 menerapkan konsep perpindahan kalor dalam kehidupan sehari-hari.

Dalam penyusunan instumen penelitian, terlebih dahulu dibuat kisi-kisi. Kisi-kisi yang dibuat dengan berpedoman pada kurikulum 2013. Sebelum instrument digunakan, terlebih dahulu dilakukan uji pakar terlebih dahulu, uji pakar dilakukan oleh dua orang pakar guna mendapat kualitas tes yang baik. Setelah selesai dilakukan expert judgment maka instrument diujicobakan ke lapangan untuk mengetahui validitas dan reliabilitas instrument tersebut. Data uji validitas butir kuesioner motivasi belajar menggunakan rumus Product Moment dibantu dengan Microsoft excel 2007 dan uji reliabilitas kuesioner belajar digunakan rumus Alpha Cronback karena datanya berbentuk politomi. Instrumen yang digunakan untuk memperoleh data tentang motivasi berupa kuesioner yang berjumlah 50 pernyataan. Instrumen yang digunakan untuk memperoleh data hasil belajar berupa soal pilihan ganda berjumlah 30 soal. Tes tersebut diuji coba lapangan untuk mencari validitas, reliabilitas, tingkat kesukaran, dan daya beda. Berdasarkan uji pakar dan uji lapangan, maka kuesioner motivasi belajar pernyataan yang valid sebanyak 30 butir pernyataan dan 20 butir pernyataan gugur, sedangkan butir soal tes hasil belajar IPA yang valid adalah 25 soal dan 5 soal gugur. Dengan demikian hasil tes uji coba diberikan kepada siswa kelas eksperimen dan kelas kontrol sebagai post-test. Teknik analisis data yang digunakan adalah satistik deskriptif dan statistik inferensial melalalui Uji-t dan Manova.

Hipotesis dalam penelitian ini adalah a) terdapat pengaruh yang signifikan model pembelajaran Scramble berbantuan kartu pertanyaan terhadap motivasi belajar IPA siswa kelas V Gugus XIII Kecamatan Buleleng, b) terdapat pengaruh yang signifikan model pembelajaran Scramble berbantuan kartu pertanyaan terhadap hasil belajar IPA siswa kelas V Gugus XIII Kecamatan Buleleng, c) secara simultan terdapat pengaruh yang signifikan model pembelajaran Scramble berbantuan kartu pertanyaan terhadap motivasi belajar dan hasil belajar IPA siswa kelas V Gugus XIII Kecamatan Buleleng. Dalam pengujian hipotesis 1 dan 2 pada penelitian menggunakan Uji-T, sedangkan pengujian hipotesis 3 dilakukan dengan uji Manova. Perhitungan data menggunakan bantuan SPSS 16.00 for windows pada signifikansi 0,05 .

\section{Hasil dan pembahasan}

Deskripsi data dikelompokkan menjadi 4, yaitu: (1) motivasi belajar siswa yang mengikuti model pembelajaran Scramble berbantuan kartu pertanyaan, (2) hasil belajr IPA siswa yang mengikuti model pembelajaran Scramble berbantuan kartu pertanyaan, (3) motivasi belajar siswa yang tidak dibelajarkan model pembelajaran Scramble berbantuan kartu pertanyaan, (4) hasil belajar IPA siswa yang tidak dibelajarkan model pembelajaran Scramble berbantuan kartu pertanyaan. Rangkuman statistik hasil analisis deskriptif dapat dilihat pada Tabel 03

Tabel 03. Rangkuman Stastistk Hasil Analisis Deskriptif

\begin{tabular}{lccccc}
\hline & Data & \multicolumn{3}{c}{ A1 } & \multicolumn{3}{c}{ A2 } \\
\cline { 2 - 6 } Statistik & Y1 & Y2 & Y1 & Y2 \\
\hline $\mathrm{N}$ & 27 & 27 & 26 & 26 \\
Mean $(\mathrm{X})$ & 135,19 & 21,11 & 128,92 & 18,15 \\
Median & 135,00 & 22,00 & 129,00 & 18,00 \\
Modus & 135 & 20 & 129 & 16 \\
\hline
\end{tabular}




\begin{tabular}{lcccc} 
Standar Deviasi (SD) & 2,67 & 2,68 & 3,01 & 2,33 \\
Skor Maksimal $\left(\mathrm{X}_{\text {maks }}\right)$ & 140 & 25 & 134 & 14 \\
Skor Minimal $\left(\mathrm{X}_{\text {minim }}\right)$ & 130 & 15 & 123 & 23 \\
\hline
\end{tabular}

Keterangan:

$\mathrm{A}_{1} \mathrm{Y}_{1}$ : Deskripsi data motivasi belajar siswa yang mengikuti model Scramble berbantuan kartu pertanyaan

$\mathrm{A}_{1} \mathrm{Y}_{2}$ : Deskripsi data hasil belajar IPA siswa yang mengikuti model Scramble berbantuan kartu pertanyaan

$\mathrm{A}_{2} \mathrm{Y}_{1}$ : Deskripsi data motivasi belajar yang mengikuti pembelajaran tidak mendapat perlakuan model pembelajaran Scramble berbantuan kartu pertanyaan

$\mathrm{A}_{2} \mathrm{Y}_{2}$ : Deskripsi data hasil belajar IPA siswa yang mengikuti pembelajaran tidak mendapat perlakuan model pembelajaran Scramble berbantuan kartu pertanyaan

Berdasarkan Tabel 03 diatas, dapat disimpulkan bahwa,(1) motivasi belajar siswa yang mengikuti model pembelajaran Scramble berbantuan kartu pertanyaan berada pada kategori sangat tinggi dengan rata-rata yang diperoleh adalah 135,19, (2) hasil belajr IPA siswa yang mengikuti model pembelajaran Scramble berbantuan kartu pertanyaan berada pada kategori sangat tinggi dengan rata-rata yang diperoleh adalah 21,11 , (3) motivasi belajar siswa yang tidak dibelajarkan model pembelajaran Scramble berbantuan kartu pertanyaan berada pada kategori tinggi dengan rata-rata yang diperoleh adalah 128,92, (4) hasil belajar IPA siswa yang tidak dibelajarkan model pembelajaran Scramble berbantuan kartu pertanyaan berada pada kategori tinggi dengan rata-rata yang diperoleh adalah 18,15.

Sebelum melakuan uji hipotesis, terlebih dahulu dilakukan pengujian prasyarat analisis terhadap sebaran data yang diperoleh, meliputi uji normalitas sebaran data, uji homogenitas varians, dan uji korelasi antar variabel terikat. Normalitas sebaran data di uji dengan teknik Kolmogrov-Smirnov dan Shapiro-Wilk dengan bantuan program SPSS 16.00 for windows diperoleh hasil seperti yang disajikan pada Tabel 04 .

Tabel 04. Hasil Uji Normalitas

\begin{tabular}{|c|c|c|c|c|c|c|c|}
\hline & \multicolumn{7}{|c|}{ Tests of Normality } \\
\hline & & \multicolumn{3}{|c|}{ Kolmogorov-Smirnov a } & \multicolumn{3}{|c|}{ Shapiro-Wilk } \\
\hline & & Statistic & Df & Sig. & Statistic & $\mathrm{Df}$ & Sig. \\
\hline \multirow[t]{2}{*}{ Motivasi Belajar } & A1Y1 & .120 & 27 & .200 & .973 & 27 & .679 \\
\hline & $\mathrm{A} 2 \mathrm{Y} 1$ & .202 & 26 & .008 & .939 & 26 & .124 \\
\hline \multirow[t]{2}{*}{ Hasil Belajar } & $\mathrm{A} 1 \mathrm{Y} 2$ & .150 & 27 & .122 & .947 & 27 & .182 \\
\hline & $\mathrm{A} 2 \mathrm{Y} 2$ & .152 & 26 & .128 & .957 & 26 & .340 \\
\hline
\end{tabular}

Berdasarkan Tabel 04 di atas, dapat dilihat bahwa semua variabel angka statistik KolmogrovSmirnov lebih besar dari 0,05. Dengan demikian maka sebaran data berdistribusi normal. Pengujian homogenitas dalam penelitian ini dilakukan dengan menggunakan uji Box's $M$ dengan bantuan SPSS 16.00 for windows. Hasil uji homogenitas menggunakan uji Box's $M$ dapat dilihat pada Tabel 05.

Tabel 05. Hasil Analisis Uji Box's Homogenitas Matriks Varians

\begin{tabular}{ll}
\hline Box"s M & 1,842 \\
F & 0,588 \\
df1 & 3 \\
df2 & 4,9195 \\
Sig & 0.623 \\
\hline
\end{tabular}

Uji homogenitas secara bersama-sama menggunakan bahwa harga Box's $M$ sebesar 1,842 dengan menghasilkan angka signifikasi sebesar 0,623. Hasil analisis menunjukkan bahwa angka signikansi dihasilkan menunjukkan nilai 0,05, maka disimpulkan bahwa matriks dari variabel dependen adalah 
homogen, sehingga hipotesis menggunakan analisis Manova dapat dilanjutkan. Menguji korelasi antar variabel terikat dilakukan dengan menggunakan korelasi Person's Product Moment dimana dalam analisis yang dilakukan ini menggunakan bantuan SPSS 16,00 for windows pada taraf signifikasi 5\%. Apabila taraf signifikansi (sig) pada hasil analisis menunjukkan nilai di atas 0,05 (sig > 0,05), maka dapat disimpulkan tidak ada korelasi antar variabel terikat maka uji hipotesis dilanjutkan dengan Manova. Hasil korelasi antar variabel terikat dalam penelitian ini dapat dilihat pada Tabel 06.

Tabel 06. Hasil Uji Korelasi Variabel Terikat antara Motivasi Belajar dengan Hasil Belajar IPA pada Kelas Eksperimen

\begin{tabular}{lll}
\hline Nilai rhitung & Taraf Signifikansi & Keputusan \\
(Person Correlation) & $($ Sig) & \\
0,005 & 0,520 & Tidak Signifikan \\
\hline
\end{tabular}

Tabel 06 menunjukkan bahwa person correlation 0.005 dengan taraf signifikansi sebesar 0,520 atau lebih dari 0,05 (Sig > 0,05). Ini menunjukkan bahwa tidak ada korelasi antar varibel motivasi belajar dengan hasil belajar IPA pada kelas eksperimen. Sehingga, uji Manova layak untuk dilakukan.

Tabel 07. Hasil Uji Korelasi Variabel Terikat antara Motivasi Belajar dengan Hasil Belajar IPA pada Kelas Kontrol

\begin{tabular}{lll}
\hline Nilai r hitung & Taraf Signifikansi & Keputusan \\
(Person Correlation) & $($ Sig) & \\
0,052 & 0,385 & Tidak Signifikan \\
\hline
\end{tabular}

Tabel 07 menunjukkan bahwa person correlation 0.052 dengan taraf signifikansi sebesar 0,385 atau lebih dari 0,05 (Sig > 0,05). Ini menunjukkan bahwa tidak ada korelasi antar varibel motivasi belajar dengan hasil belajar IPA pada kelas kontrol. Sehingga, uji Manova layak untuk dilakukan.. Uji hiptotesi ke-1 dan ke-2 dilakukan dengan analisis test of between-subjects effects. Sedangkan hipotesis ke-3 diuji dengan analisis multivariate (MANOVA). Hasil pengujian hipotesis 1 dan 2 dengan bantuan SPSS 16.0 for windows disajikan pada Tabel 08.

Tabel 08. Hasil Uji Hipotesis 1 dan 2 dengan analisis varian Test of Between-Subjects Effects

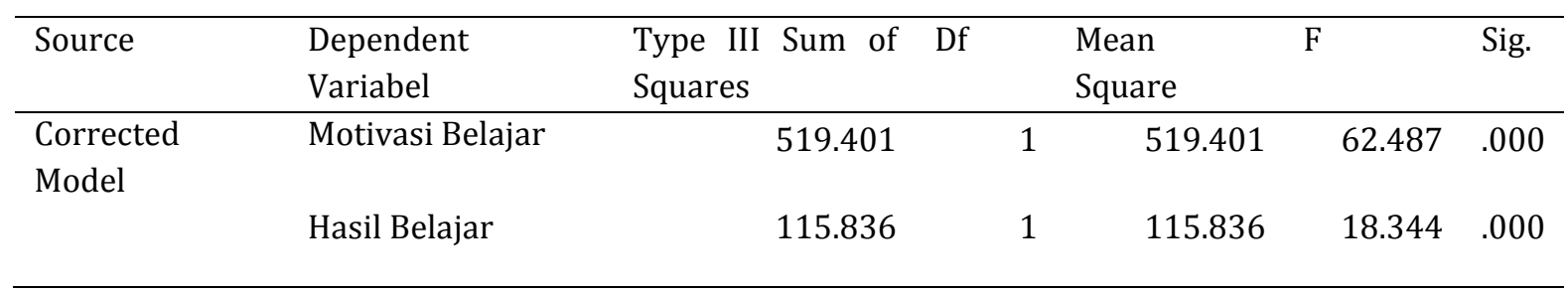

Pada Tabel 08 menunjukkan hasil motivasi belajar pada kolom Corrected Model sebesar 0.000 dan lebih kecil dari 0,05. Sehingga dapat disimpulkan bahwa hipotesis (H0) ditolak dan hipotesis alternative (Ha) diterima. Hal ini berarti bahwa terdapat pengaruh yang signifikan model pembelajaran Scramble berbantuan kartu pertanyaan terhadap motivasi belajar IPA siswa kelas V Gugus XIII Kecamatan Buleleng Tahun Pelajaran 2019/2020. Sedangkan hasil hasil belajar IPA pada kolom Corrected Model sebesar 0.000 dan lebih kecil dari 0,05. Sehingga dapat disimpulkan bahwa hipotesis (H0) ditolak dan hipotesis alternative (Ha) diterima. Hal ini berarti bahwa terdapat pengaruh yang signifikan model pembelajaran Scramble berbantuan kartu pertanyaan terhadap hasil belajar IPA siswa kelas V Gugus XIII Kecamatan Buleleng Tahun Pelajaran 2019/2020. Selanjutnya hipotesis ke-3 diuji dengan analisis Multivariate Analysis of Varians (MANOVA) dengan bantuan SPSS 16.00 for windows. Hasil Pengujian hipotesis 3 tersaji pada Tabel 09. 
Tabel 09. Hasil Analisis Uji Hipotesis 3 dengan uji analisis Multivariat

Multivariate Tests ${ }^{c}$

\begin{tabular}{clccccc}
\hline \multirow{2}{*}{ Intercept } & Value & F & $\begin{array}{c}\text { Hypothesis } \\
\mathrm{df}\end{array}$ & Error df & Sig. \\
& Pillai's Trace & 1.000 & $5.976 \mathrm{E} 4^{\mathrm{a}}$ & 2.000 & 50.000 & .000 \\
\cline { 2 - 7 } & Wilks' Lambda & .000 & $5.976 \mathrm{E} 4^{\mathrm{a}}$ & 2.000 & 50.000 & .000 \\
\cline { 2 - 7 } & $\begin{array}{c}\text { Hotelling's } \\
\text { Trace }\end{array}$ & $2.390 \mathrm{E} 3$ & $5.976 \mathrm{E} 4^{\mathrm{a}}$ & 2.000 & 50.000 & .000 \\
\cline { 2 - 7 } & $\begin{array}{c}\text { Roy's Largest } \\
\text { Root }\end{array}$ & $2.390 \mathrm{E} 3$ & $5.976 \mathrm{E} 4^{\mathrm{a}}$ & 2.000 & 50.000 & .000 \\
\hline \multirow{2}{*}{ Kelas } & \begin{tabular}{c} 
Pillai's Trace \\
\cline { 2 - 7 }
\end{tabular} & .553 & $30.964^{\mathrm{a}}$ & 2.000 & 50.000 & .000 \\
\cline { 2 - 7 } Wilks' Lambda & .447 & $30.964^{\mathrm{a}}$ & 2.000 & 50.000 & .000 \\
\hline $\begin{array}{c}\text { Hotelling's } \\
\text { Trace }\end{array}$ & 1.239 & $30.964^{\mathrm{a}}$ & 2.000 & 50.000 & .000 \\
\cline { 2 - 7 } & $\begin{array}{c}\text { Roy's Largest } \\
\text { Root }\end{array}$ & 1.239 & $30.964^{\mathrm{a}}$ & 2.000 & 50.000 & .000 \\
\hline
\end{tabular}

Berdasarkan hasil analisis pada Tabel 09, nilai $\mathrm{F}$ hitung Pillai's Trace (F hitung $=30.964$ ), Hottelling's Trace $(\mathrm{F}$ hitung $=30.964)$, Roy Largest Root $(\mathrm{F}$ hitung $=30.964)$, seluruhnya memiliki sig. sebesar 0.00 . Hasil perhitungan tersebut menunjukkan bahwa sig. lebih kecil dari 0.05 , sehingga hipotesis nol $\left(\mathrm{H}_{0}\right)$ ditolak dan hipotesis alternative $\left(\mathrm{H}_{\mathrm{a}}\right)$ diterima. Jadi secara simultan terdapat pengaruh yang signifikan model pembelajaran Scramble berbantuan kartu pertanyaan terhadap motivasi belajar dan hasil belajar IPA siswa kelas V Gugus XIII Kecamatan Buleleng. Berdasarkan pada hasil pengujian hipotesis yang telah diuraikan sebelumnya ketiga hipotesis yang diajukan pada penelitian ini berhasil menolak hipotesis nol, Berikut adalah rangkuman dari hasil uji hipotesis yang telah dilakukan.

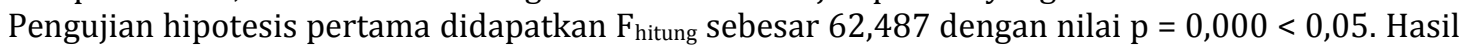
tersebut menunjukkan bahwa hipotesis nol yang berbunyi Tidak terdapat pengaruh model pembelajaran Scramble berbantuan kartu pertanyaan terhadap motivasi belajar IPA siswa kelas V Gugus XIII Kecamatan Buleleng Tahun Pelajaran 2019/2020, ditolak dan hipotesis alternative diterima.

Skor rata-rata motivasi belajar siswa yang mengikuti model Scramble berbantuan kartu pertanyaan adalah sebesar 135,1 lebih besar dibandingkan dengan siswa yang tidak dibelajarkan dengan model pembelajaran Scramble berbantuan kartu pertanyaan yaitu sebesar 128,92. Hal ini didapat menjadi pertimbangan guru agar menjadikan model pembelajaran Scramble berbantuan kartu pertanyaan sebagai salah satu model yang baik digunakan dalam proses pembelajaran.

Perbedaan motivasi belajar kelas ekperimen dan kelas kontrol terjadi karena perlakuan yang diberikan. Pada kelas ekperimen proses pembelajaran menerapkan model pembelajaran Scramble berbantuan kartu pertanyaan sedangkan di kelas kontrol tidak menerapkan model pembelajaran Scramble berbantuan kartu pertanyaan. Hasil temuan yang diperoleh dalam penelitian dilakukan, bahwa siswa sangat bersemangat, antusias siswa dalam belajar juga terlihat siswa secara bekerjasama dengan anggota kelompoknya untuk memecahkan masalah yang diberikan oleh guru, berbeda halnya dengan siwa yang pembelajaran dengan tidak mendapat perlakuan model Scramble berbantuan kartu pertanyaan siswa nampak kurang semangat mengikuti pembelajaran dan terlihat dari siswa merasa bosan saat mengikuti pembelajaran. Maka dengan itu, sebagai guru tidak hanya mengajar siswa tetapi dapat memotivasi siswa dalam belajar.

Hasil penelitian ini sejalan dengan pendapat Uno (2008) motivasi belajar sebagai suatu dorongan dasar yang dapat menggerakkan seseorang dalam bertingkah laku. Dorongan ini berasal dari diri seseorang yang dapat menggerakkan untuk melakukan sesuatu yang sesuai dengan dorongan pada dalam dirinya. Sejalan dengan pendapat Hamdu dan Lisa (2011) motivasi adalah suatu usaha yang disadari untuk menggerakkan, menggarahkan dan menjaga tingkah laku seorang agar terdorong dalam bertindak melakukan sesuatu untuk mencapai hasil tujuan yang diharapkan. Adapun faktor yang dapat mempengaruhi motivasi belajar siswa antara lain: (1) kondisi fisik dan psikis dari peserta didik; (2) kondisi lingkungan; (3) upaya seorang guru dalam melakukan kegiatan pembelajaran di sekolah; dan (4) pemberian reward juga dapat mempengaruhi motivasi belajar dari peserta didik. 
Adanya perbedaan skor tersebut disebabkan oleh model pembelajaran Scramble merupakan salah satu model pembelajaran permainan yang mendukung terciptanya suatu pembelajaran yang bermakna dan menyenangkan bagi siswa sehingga dapat meningkatkan segala potensinya yang dimilki oleh masing-masing siswa sehingga dapat meningkatkan motivasi belajar siswa. Hal ini sejalan dengan pendapat Saridewi, dkk. (2017) bahwa model pembelajaran scramble merupakan salah satu strategi pembelajaran motivasional yang diyakini dapat meningkatkan motivasi dan prestasi siswa dalam belajar. Selain model pembelajaran Scramble, agar pembelajaran lebih optimal dipadukan dengan media kartu pertanyaan. Media kartu pertanyaan adalah sarana agar siswa belajar secara aktif terlibat dalam kegiatan belajar, berpikir kritis di dalam belajar secara inovatif. Dengan penggunaan kartu pertanyaan bertujuan untuk memudahkan siswa dalam berinteraksi dalam belajar sehingga melalui media ini dapat menarik perhatian siswa dan dapat meningkatkan pemahaman siswa.

Berdasarkan hasil analisis dan temuan dalam penelitian ini yang sesuai dengan penelitian ini, sehingga dapat disimpulkan bahwa terdapat pengaruh yang signifikan model pembelajaran Scramble berbantuan kartu pertanyaan terhadap motivasi belajar IPA siswa kelas V Gugus XIII Kecamatan Buleleng.

Pengujian hipotesis kedua didapatkan $\mathrm{F}_{\text {hitung }}$ sebesar 18.344 dengan nilai $\mathrm{p}=0,000<0,05$. Hasil tersebut menunjukkan bahwa hipotesis nol yang berbunyi Tidak terdapat pengaruh model pembelajaran Scramble berbantuan kartu pertanyaan terhadap hasil belajar IPA siswa kelas V Gugus XIII Kecamatan Buleleng Tahun Pelajaran 2019/2020, ditolak dan hipotesis alternative diterima.

Skor rata-rata siswa yang dibelajarkan model Scramble berbantuan kartu pertanyaan adalah 21,11 . Sedangkan, siswa yang tidak dibelajarkan model pembelajaran Scramble berbantuan kartu pertanyaan memperoleh skor rata-rata 18,15. Dari hasil tersebut dapat disimpulkan bahwa hasil beajar IPA yang dibelajarkan dengan model pembelajaran Scramble berbantuan kartu pertanyaan menunjukkan hasil yang lebih baik dari pada siswa yang tidak dibelajarkan model pembelajaran Scramble berbantuan kartu pertanyaan.

Perbedaan hasil belajar kelas ekperimen dan kelas kontrol terjadi karena perbedaan perlakuan yang diberikan. Pada kelas ekperimen proses pembelajaran menerapkan model pembelajaran Scramble berbantuan kartu pertanyaan sedangkan pada kelas kontrol tidak menerapkan model pembelajaran Scramble berbantuan kartu pertanyaan disebabkan oleh beberapa faktor. Faktor pertama, pada proses pembelajaran Scramble adalah model pembelajaran yang menyediakan kartu soal dan kartu jawaban yang diacak sehingga mendororong siswa untuk dapat memecahkan masalah sehingga menekankan suasana belajar yang kondusif dan menyenangkan, sehingga dalam pembelajaran siswa diajak bermain sambil belajar. Tidak hanya itu, siswa dalam pembelajaran berkompetisi untuk maju dan siswa antusias dalam memecahkan masalah sehingga dalam kelompok siswa saling bekerjasama memecahkan soal-soal yang diberikan oleh guru. Hal ini sejalan dengan pendapat dari penelitian Ramadani, dkk. (2014) model pembelajaran Scramble berbantuan kartu pertanyaan dapat membantu siswa dalam menumbuhkan keaktifan dan keantusiasan dalam mengikuti proses pembelajaran. Hasil penelitian ini menguatkan beberapa hasil penelitian yang ditemukan, diantaranya penelitian yang dilakukan oleh Aritni (2014) Badruzzaman dan Sumardi (2013) menyatakan bahwa model pembelalajaran kooperatif tipe Scramble memberikan pengaruh yang postif terhadap hasil belajar IPS. Dengan itu, model pembelajaran Scramble dapat memberikan peluang kepada siswa untuk aktif serta dapat mengkontruksikan pengetahuan siswa di dalam mengaitkan konsep-konsep materi yang dapat diingat dan dipahami oleh siswa dengan menyenangkan dalam kelompok belajarnya juga dituntut kerjasama, kekompakan di dalam memecahkan soal.

Parveen (2012) dan Isik dan Tarim (2009) menemukan bahwa stategi pembelajaran kooperatif lebih unggul dari pembelajaran tradisional atau yang berpusat pada guru. Hal ini karena di dalam pembelajaran kooperatif ini melibatkan siswa secara aktif di dalam memecahkan masalah sehingga pembelajaran menjadi menyenangkan. Sehingga siswa di dalam kelompok secara bekerjasama dan memilki tanggung jawab terhadap segala ssuatu yang dikerjakan .

Faktor kedua, yang menyebabkan adanya perbedaan hasil belajar IPA adalah penggunaan media pembelajaran pada kelas eksperimen yaitu media kartu pertanyaan. Penggunaan media pembelajaran dapat merangsang minat motivasi siswa dalam mengikuti pembelajaran. Kelebihan dari media kartu pertanyaan adalah siswa dapat memecahkan masalah melalui soal yang ada pada kartu pertanyaan secara mandiri maupun berkelompok sehingga menumbuhkan keterampilan berpikir kritis siswa dalam memecahkan masalah melalui kartu pertanyaan.

Penggunaan media dalam model pembelajaran Scramble berbantuan kartu pertanyaan membawa pengaruh positif terhadap proses belajar siswa yaitu peningkatan motivasi dan hasil belajar siswa pada pelajaran IPA. Kelebihan dari model pembelajaran Scramble: 1) siswa dalam belajar sambil bermain, sehingga siswa secara dapat lebih santai dalam mengikuti pembelajaran, 2) dalam proses pembelajaran 
materi yang diberikan di kelas akan lebih mengesankan dan sulit dilupakan, 3) menimbulkan kegembiraan dan melatih keterampilan siswa dalam memecahkan masalah sehingga siswa bekerjasama dalam kelompok.

Berbeda dengan kelas yang tidak menggunakan mode model Scramble berbantuan kartu pertanyaan yang masih berpusat pada guru (teacher centered.). Dimana selama kegiatan pembelajaran guru cenderung lebih mendominasi kegiatan pembelajaran. Pendapat tersebut sejalan dengan pendapat Rasana (2009) pembelajaan konvensional guru yang lebih aktif dikelas dan siswa menjadi pasif dalam mengikuti proses pembelajaran. Selama kegiatan belajar siswa hanya mendengar penjelasan materi yang disampaikan oleh guru tanpa ada interaksi antar siswa, sehingga proses pembelajaran ini menjadi kurang bermakna dan menyenangkan serta akan berdampak pada skor hasil belajar IPA siswa yang rendah.

Hipotesis ketiga didapatkan hasil bahwa nilai signifikansi lebih kecil dari 0,05 $(\mathrm{p}=0,000<0,005)$. Uji Manova tersebut dilakukan untuk mengetahui pengaruh model pembelajaran Scramble berbantuan kartu pertanyaan terhadap motivasi dan hasil belajar IPA.

Kriteria pengujian hipotesis yang digunakan adalah apalabila $\mathrm{p}<0,005$ maka $\mathrm{H}_{0}$ ditolah dan $\mathrm{H}_{\mathrm{a}}$ diterima, sebalikanya jika $\mathrm{p}>0,05$ maka $\mathrm{H}_{0}$ diterima dan $\mathrm{H}_{\mathrm{a}}$ ditolak. Hasil uji hipotesis Manova diatas menunjukkan bahwa nilai signifikansi menunjukkan bahwa lebih kecil dari 0,05 yang berarti $\mathrm{H}_{0}$ ditolak. Oleh karena itu hipotesis nol yang menyatakan bahwa secara simultan tidak terdapat pegaruh model pembelajaran Scramble berbantuan kartu pertanyaan terhadap motivasi dan hasil belajar IPA siswa kelas V Gugus XIII Kecamatan Buleleng Tahun Pelajaran 2019/2020, ditolak dan hipotesis alternative diterima.

Model pembelajaran yang inovatif, menyenagkan dan berorientasi pada peserta didik cenderung meningkatkan daya ingat siswa, karena siswa langsung merasakan dan mengerjakan.Sesuai dengan langkah-langkah model pembelajaran Scramble yaitu: (1) Buatlah kartu soal sesuai dengan materi bahan ajar, (2) Buat kartu jawaban dengan diacak, (3) Sajian materi, (4) membagi kartu soal pada kelompok dan kartu jawaban, (5) siswa berkelompok mengerjakan soal dan mencari kartu soal untuk jawaban yang cocok. Model pembelajaran Scramble merupakan model pembelajaran yang inovatif menyenangkan dan berorientasi pada peserta didik (student centered). Hal ini diperkuat penelitian Putra, dkk. (2014) model pembelajaran Scramble sebagai sebuah pembelajaran yang inovatif mampu menciptakan pembelajaran yang menyenangkan kepada peserta didik. Penerapan model ini dapat menimbulkan motivasi pada diri peserta didik sehingga secara tidak langsung dapat mempengaruhi proses belajar dar peserta didik. Sejalan dengan pendapat Murti, (2016) dengan model Scramble pembelajaran akan memberikan motivasi kepada siswa untuk belajar secara mendalam melalui pengamatan secara nyata sehingga siswa siswa tidak cepat bosan dan mengantuk dalam belajar karena dalam pembelajaran Scramble siswa dilibatkan secara penuh dan belajar akan menjadi menyengkan dan bermakna sehingga peserta didik dapat memahami materi yang diajarkan oleh guru. Selain model pembelajaran pemilihan media juga sangat diperlukan salah satunya yaitu media kartu pertanyaan.

Penggunaan media kartu pertanyaan dalam pembelajaran IPA dalam model pembelajaran Scramble siswa menyelesaikan dengan menyusun pasangan dari konsep secara kreatif dengan menyusun huruf-huruf yang disusun secara acak sehingga akan membentuk suatu jawaban. Dengan cara tersebut dapat membantu siswa meningkatkan hasil belajar IPA dan motivasi belajar serta menciptakan pembelajaran yang bermakna dan menyenangkan bag siswa, karena siswa akan lebih mudah mengingat informai-informasi atau materi-materi yang dipelajari oleh siswa tersebut.

Hasil temuan yang diperoleh dilapangan menunjukkan kelompok siswa yang mengikuti model pembelajaran Scramble, siswa terlihat sangat aktif, siswa lebih memperhatikan penjelasan guru dengan baik dan siswa antusias siswa dalam mengikuti proses pembelajaran, dan siswa saling bekerjasama dan kreatif dalam kelompok saat menyusun jawaban yang diacak yang harus disempurnakan menjadi jawaban yang benar kemudian dipasangkan dengan kartu pertanyaan pertanyaan. Dengan demikian ingatan serta pemahaman terhadap pembelajaran IPA menjadi bertahan lama. hal ini akan berpengaruh positif terhadap motivasi dan hasil belajar siswa. Temuan ini sejalan dengan penelitian yang dilakukan oleh Azizah (2018) dengan penelitian yang berjudul "Peningkatan Motivasi dan Hasil Belajar IPA melalui Penerapan Model Scramble Siswa Kelas IIIB SDN Temmalebba" berdasarkan hasil penelitiannya motivasi dan hasil pembelajaran IPA di Kelas IIIB SDN Temmalebba dengan menerapkan model scramble dilakukan menunjukkan peningkatan. Selanjutnya penelitian yang dilakukan oleh Ernayanti (2016) dengan penelitian berjudul Pengaruh Model Pembelajaran Think Talk Write Terhadap Motivasi dan Hasil Belajar Bahasa Pada siswa Kelas IV SD dengan hasil menunjukkan bahwa terjadi peningkatan motivasi dan hasil belajar bahasa Indonesia. Penelitian selanjutnya dilakukan dengan Pertiwi (2017) dengan judul penelitian Pengaruh Model Problem Based Learning Bermuatan Budaya Lokal Terhadap Motivasi belajar dan hasil belajar IPS Kelas V SD Gugus XIII Kecamatan Tejakula. 
Berbeda dengan dengan pembelajaran IPA yang tidak menggunakan model pembelajaran Scramble berbantuan kartu pertanyaan menujukkan bahwa dalam proses pembelajaran lebih banyak siswa mendengar penjelasan guru karena guru dalam mengajar hanya menggunakan metode ceramah. Hal ini terlihat bahwa pembelajaran menjadi kurang menyengkan dan bermakna sehingga kurang meningkatkan motivasi belajar dan hasil belajar IPA siswa, karena guru lebih banyak menyampaikan materi dan membuat siswa menjadi merasa bosan dan jenuh saat mengikuti pembelajaran.

Dari uraian di atas, dapat diambil kesimpulan bahwa penerapan model Scramble berbantuan kartu pertanyaan efektif diterapkan untuk meningkatkan motivasi belajar dan hasil belajar siswa IPA siswa kelas V Gugus XIII Kecamatan Buleleng.

\section{Simpulan dan saran}

Berdasarkan hasil penelitian dan pembahasan, Uji Test Of Between-Subject Effects didapatkan nilai signifikansi motivasi belajar pada kolom Corrected Model sebesar 0,000 dan lebih kecil dari 0,05. Jadi, dapat disimpulkan bahwa terdapat pengaruh yang signifikan model pembelajaran Scramble berbantuan kartu pertanyaan terhadap motivasi belajar siswa kelas V SD Gugus XIII Kecamatan Buleleng; Berdasarkan hasil penelitian dan pembahasan untuk hipotesis 2 bahwa berdasrkan Uji Test Of BetweenSubject Effects didapatkan nilai signifikansi hasil belajar IPA pada kolom Corrected Model sebesar 0,000 dan lebih kecil dari 0,05. Jadi, dapat disimpulkan bahwa terdapat pengaruh yang signifikan model pembelajaran Scramble berbantuan kartu pertanyaan terhadap hasil belajar IPA siswa kelas V SD Gugus XIII Kecamatan Buleleng; Berdasarkan hasil penelitian dan pembahasan, didapatkan nilai signifikan Pillai's, Wilk's Lambda, Hotteling's Trance, dan Roy's Largest Root sebesar 0,000 dan lebih kecil 0,05. Jadi, dapat disimpulkan bahwa secara simultan terdapat pengaruh yang signifikan model pembelajaran Scramble berbantuan kartu pertanyaan terhadap motivasi belajar dan hasil belajar IPA siswa kelas V Gugus XIII Kecamatan Buleleng.

Berdasarkan temuan dalam penelitian ini menunjukkan bahwa variabel penelitian tentang pengaruh model pembelajaran Scramble berbantuan kartu pertanyaan berkontribusi positif terhadap motivasi belajar dan hasil belajar IPA siswa kelas V Gugus XIII Kecamatan Buleleng. Beberapa saran terkait dengan penelitian ini adalah sebagai berikut. 1) siswa hendaknya agar selalu terlibat aktif dalam proses pembelajaran dengan menggunakan model pembelajaran Scramble berbantuan kartu pertanyaan sehingga pengetahuan benar-benar dipahami dan melekat dalam ingatan siswa; 2) guru disarankan agar menciptakan suasana aktif dengan menggunakan pendekatan yang inovatif dan menekankan pada keaktifan siswa seperti menerapakan model pembelajaran scramble berbantuan kartu pertanyaan sesuai dengan materi pelajaran dan karakteristik siswa di sekolah; 3) kepala sekolah disarankan agar dapat memfasilitasi rekan-rekan guru lainnya agar mampu menggunakan berbagai model pembelajaran yang bervariasi seperti menerapkan model pembelajaran Scramble berbantuan kartu pertanyaan dalam proses pembelajaran di skolah sehingga siswa dapat termotivasi dalam belajar dan mencapai hasil belajar yang maksimal; 4) bagi peneliti selanjutnya diharapkan memperhatikan kendala-kendala yang dialami dalam pelaksanaan penerapan model pembelajaran Scramble berbantuan kartu pertanyaan pada mata pelajaran IPA atau ilmu bidang lainnya sebagai bahan pertimbangan untuk perbaikan dan penyempurnaan penelitian yang dilaksanakan.

\section{Daftar Rujukan}

Agung, A. A. Gede. 2014. Metodelogi Penelitian Pendidikan. Aditya Media Publishing.

Arsyad, A. (2017). Media Pembelajaran. Jakarta: Rajawali Pers.

Artini, Anak Agung Ayu Sri Vidya. 2014. Pengaruh Model Pembelajaran Scramble Berbantuan Media Semi Konkret terhadap Hasil Belajar IPS Siswa Kelass V SD Gugus Kapten Kompiang Sujana Denpasar Barat Tahun Ajaran 2013/2014. E-Journal PGSD Undiksha, Vol: 2 No: 1 Tahun 2014.

Astriani, L Widi dan I Km Sudarma. 2019. Pengaruh Model Pembelajaran Scramble Berbantuan Kartu Gambar Terhadap Hasil Belajar IPA siwa kelas V gugus II Kecamatan Kubutambahan. Jurnal Pedagogik dan Pembelajaran. Vol 2.

Azizah, Nur. 2018. Peningkatan Motivasi Dan Hasil Belajar IPA Melalui Penerapan Model Scramble Pada Siswa Kelas IIIB SDN 24 Temmalebba Kota Palopo.

Citrasmi, Ni Wayan, I Nyoman Wirya, dan I. M. T. (2016). Pengaruh Model Pembelajaran Scramble Berbantuan Media Gambar Terhadap Hasil Belajar IPA di SD Semarapura Tengah Kecamatan 
Klungkung. E-Jurnal Universitas Pendidikan Ganesha, 4(1), 1-10.

Ernayanti, Luh Gede Dita, I Nyoman Dantes, Desak Putu Parmiti. 2016. Pengaruh Model Pembelajaran Think Talk Write Terhadap Motivasi dan Hasil Belajar Bahasa Indonesia pada siswa kelas IV SD di Gugus III Tambora Kecamatan Melaya. e-Journal PGSD Undiksha Singaraja. Vol 4. No. 1.

Farida, Umul, dkk. 2017. Efektivitas Model Pembelajaran Scramble Berbasis Kontekstual Terhadap Kemampuan Berpikir Kritis Ips Siswa Kelas Iii Sd Negeri Kebondalem 01 Batang. Jurnal Ilmiah Sekolah Dasar, 1(3). 192-199.

Gull F., Shehzad S. 2015. Effects of Cooperative on Students academic Achievement. Journal of Education and Learning. Vol 9 (3).

Hamdu, Ghullam dan Lisa Agustina. 2011. Pengaruh Motivasi Belajar Siswa terhadap Prestasi Belajar IPA di Sekolah Dasar. Jurnal Penelitian Pendidikan, 12(1), (90-96).

Isik, Dillek dan Tarim Kamuran. 2009. The Effects of Cooperative Learning Method Supported by Multiple Intellegence Theory of Turkish Elementary Study Mathematics achievement. Education Research Insitute, Seoul National University, Seoul, Korea.

Murti, I. G. A. (2016). Model Pembelajaran Scramble Berbantuan Media Gambar Terhadap Hasil Belajar IPA Siswa Kelas IV Gugus I Kecamatan Nusa Penida Semester Genap Tahun Pelajaran 2015/2016. Jurnal Mimbar PGSD Universitas Pendidikan Ganesha, 4(1).

Pertiwi, Komang Ari, I Gusti Ngurah Japa, I Kadek Suartana. 2017. Pengaruh Model Problem Based Learning Bermuatan Budaya Lokal Terhadap Motivasi belajar dan hasil belajar IPS Kelas V SD Gugus XIII Kecamatan Tejakula. e-Journal PGSD Undiksha

Putra Pande Adi, A.A. Gede Agung, dan N. M. S. (2014). Pengaruh Model Pembelajaran Scramble Berbantuan Media Permainan Teka-Teki Silang terhadap Hasil Belajar Bahasa Indonesia Siswa Kelas V SD Negeri 1 Sangsit. Jurnal Mimbar PGSD Universitas Pendidikan Ganesha, 2(1).

Ramadani, Ni Km Triana, N. W. A. dan I. N. A. (2014). Pengaruh Model Pembelajaran Scramble Berbantuan Kartu Pertanyaan Terhadap Hasil Belajar IPA Siswa Kelas V SD di Desa Dauhwaru Kecamatan Jembrana Kabupaten Jembrana Tahun Ajaran 2013/2014. Jurnal Mimbar PGSD Universitas Pendidikan Ganesha, 2(1).

Saridewi, Ni Made Putri, dan N. N. K. (2017). Penerapan Model Pembelajaran Scramble untuk Meningkatkan Hasil Belajar IPA Siswa Kelas IV SD No. 3 Legian. Jurnal Mimbar PGSD Universitas Pendidikan Ganesha, 1(3).

Suryanta, I Made, Ida Bagus Gede Surya Abadi, I. A. S. A. (2014). Pengaruh Model Pembelajaran Scramble Berbantuan Media Gambar Animasi Terhadap Hasil Belajar IPA Siswa Kelas V SD Gugus Yos Sudarso Denpasar. Jurnal Mimbar PGSD Universitas Pendidikan Ganesha, 2(1).

Suyatno. 2009. Menjelajah Seratus Pembelajaran Inovatif. Sidoarjo: Masmedia

Sya'ban, Veni Melia. 2016. Pengaruh Motede Scramble Terhadap Minat Belajar IPS Siswa Kelas V SDN Rejowinangun 1 Yogyakarta. Jurnal Pendidikan Guru Sekolah Dasar.

Parveen, Qaisara. 2012. Effect of Cooperative Learning on Achievement of Students in General Science at Secondary Level. Internasional Education Studies Vol. 5 No 2.

Rasana, I Dewa Raka. 2009. Model-model Pembelajaran. Singaraja: Undiksha.

Tran, Van Dat. 2014. The Effects of Cooperative Learning on the Acamedic Achievement and Knowledge Retention. Internasional Journal of Higher Education. Vol. 3. No. 2.

Uno, Hamzah B. 2008. Teori Motivasi \& Pengukuran. Jakarta: Bumi Aksara.

Wiandariyani, Ni Putu Yanti, Nyoman Dantes, dan T. R. P. (2011). Pengaruh Model Pembelajaran Experiential terhadap Motivasi dan Hasil Belajar IPA Siswa Kelas V SD Negeri 1 dan 3 Banjar Tegal, Kecamatan Buleleng. Jurnal Mimbar PGSD Universitas Pendidikan Ganesha, 1(1).

Widi, A. widi \& E. S. (2019). Metodologi Pembelajaran IPA. Jakarta: Bumi Angkasa.

Wisudawati, Asih Widi dan Eka Sulistyowati. 2019. Metodologi Pembelajaran IPA. Jakarta: Bumi Angkasa 